\title{
Spatiotemporal habitat use by breeding sooty shearwaters Puffinus griseus
}

\author{
Scott A. Shaffer ${ }^{1, *}$, Henri Weimerskirch ${ }^{2}$, Darren Scott ${ }^{3}$, David Pinaud ${ }^{2}$, \\ David R. Thompson ${ }^{4}$, Paul M. Sagar ${ }^{5}$, Henrik Moller ${ }^{3}$, Graeme A. Taylor ${ }^{6}$, \\ David G. Foley ${ }^{7,8}$, Yann Tremblay ${ }^{1,9}$, Daniel P. Costa ${ }^{1}$
}

\footnotetext{
${ }^{1}$ Ecology and Evolutionary Biology and Institute of Marine Sciences, University of California, 100 Shaffer Road, Santa Cruz, California 95060-5730, USA

${ }^{2}$ Centre d'Etudes Biologiques de Chizé, CNRS, 79360 Villiers en Bois, France

${ }^{3}$ Department of Zoology, University of Otago, 340 Great King Street, Dunedin, New Zealand

${ }^{4}$ National Institute of Water and Atmospheric Research, 301 Evans Bay Parade, Wellington, New Zealand

${ }^{5}$ National Institute of Water and Atmospheric Research, 10 Kyle Street, Riccarton, Christchurch, New Zealand

${ }^{6}$ Department of Conservation, PO Box 108, Kilbirnie, Wellington, New Zealand

${ }^{7}$ Joint Institute for Marine and Atmospheric Research, University of Hawaii, 1000 Pope Road, Honolulu, Hawaii 96822, USA

${ }^{8}$ National Oceanic and Atmospheric Administration, Southwest Fisheries Science Center, 1352 Lighthouse Avenue, Pacific Grove, California 93950, USA

${ }^{9}$ Centre de Recherche Halieutique Méditerranéenne et Tropicale, IRD, 34203 Sète cedex, France
}

\begin{abstract}
Breeding sooty shearwaters Puffinus griseus cycle between long (11 to $14 \mathrm{~d}$ ) and short ( 1 to 2 d) foraging bouts at sea, but no information exists on bird behavior during these trips. We tested the hypothesis that shearwaters use these long trips to travel to distant Antarctic waters compared to remaining in local waters. Patterns of habitat use of 28 breeding sooty shearwaters were studied using $6 \mathrm{~g}$ archival data loggers that recorded location, environmental temperature, and diving behavior. Dive activity was compared to remotely-sensed environmental data to characterize the habitats visited by shearwaters on long and short trips. Sooty shearwaters traveled predominantly ( $70 \%$ of all long trips) to cold oceanic waters along the Polar Front (mean \pm SD, $1970 \pm 930 \mathrm{~km}$ from colony) on long trips or remained within warmer neritic waters of the New Zealand shelf (515 \pm $248 \mathrm{~km}$ from colony) on short trips. Diving depths (mean depth $15.9 \pm 10.8 \mathrm{~m}$, max depth $69.9 \mathrm{~m}, \mathrm{n}=$ 2007 dives) were not significantly different between excursion types. Activity patterns suggest that shearwaters commuted between distant foraging grounds (e.g. Polar Front) and the breeding colony and that more than $95 \%$ of diving activity occurred during daylight hours. Although shearwaters traveled primarily to Antarctic waters on long trips, occasional trips around New Zealand waters were observed; all but 2 birds were from the northern-most study colony. Oceanic habitats in Antarctic waters were substantially different from neritic habitats around New Zealand, indicating that shearwaters experience dramatically different environmental conditions associated with each excursion type. The ability of sooty shearwaters to use 2 vastly different habitats provides greater flexibility for maximizing resource acquisition during breeding and reduces competition near the colony.
\end{abstract}

KEY WORDS: Activity · Archival data logger · Diving · Geolocation · Puffinus griseus · Tracking • Sea surface temperature $\cdot$ Sooty shearwater Resale or republication not permitted without written consent of the publisher

\section{INTRODUCTION}

Oceanic processes can create a highly dynamic and heterogeneous environment with considerable influence on biological productivity at varying spatial and temporal scales (Schneider 1994). Top marine preda- tors that rely on prey aggregated at or by these physical features are themselves ultimately connected to the dynamic nature of these processes, affecting the predators' distribution in time and space (Hunt \& Schneider 1987, Schneider 1993, Hunt et al. 1999). Thus, studies that focus on where and when top marine 
predators occur, combined with associated correlates of the physical environment, can improve our understanding of their spatio-temporal relationships of habitat use, particularly when breeding.

For top predators like seabirds that breed on land and forage at sea, parents are fundamentally constrained by the distance separating them from where and when food is acquired and the location of their nesting colony (cf. Pennycuick et al. 1984, Weimerskirch et al. 1997). Oceanic processes therefore play a pivotal role in shaping the evolution of seabird breeding strategies, because it is generally regarded that most seabird species hatch young when biological productivity in the oceans peaks (Ashmole 1971, Ricklefs 1990). Numerous studies have also shown that some seabird species (mainly albatrosses and petrels) alternate between long and short duration bouts to balance energy flow between parents and offspring (e.g. Chaurand \& Weimerskirch 1994, Weimerskirch et al. 1997, Weimerskirch 1998, Weimerskirch \& Cherel 1998). Despite the observed alternation of long and short duration bouts, there is a lack of complementary behavioral data, especially for small species $(<1 \mathrm{~kg})$, to evaluate whether birds use different marine habitats or have different activity patterns while conducting long and short trips.

By virtue of their abundance (ca. several million individuals; Brooke 2004), sooty shearwaters Puffinus griseus Gmelin, 1789 are major Southern Ocean predators. They are consummate flyers and capable divers, with the capacity to reach diving depths exceeding $60 \mathrm{~m}$ (Weimerskirch \& Sagar 1996, Shaffer et al. 2006). However, the movement patterns, at-sea activity, and habitat use of breeding birds are poorly defined. Colony-based studies of sooty shearwaters (cf. Richdale 1963) indicate that parents alternate nest attendance patterns in a cyclical manner whereby adults mix short (1 to $2 \mathrm{~d}$ ) and long (5 to $18 \mathrm{~d}$ ) duration bouts at sea (Weimerskirch 1998). Based on the number of sooty shearwaters observed at the Polar Front (Warham 1996), Weimerskirch (1998) suggested that breeding birds probably foraged in productive Antarctic waters approximately 1500 to $2000 \mathrm{~km}$ from the colony. However, without studying the movement patterns of individual birds, it is difficult to determine the plausibility of this prediction. Therefore, we used tracking tags to test the hypothesis that sooty shearwaters exploit Antarctic waters on long trips as opposed to remaining in neritic waters around New Zealand. The tracking tags were data logging devices that also recorded diving behavior and environmental temperatures (cf. Shaffer et al. 2005, 2006), so we were able to characterize at-sea activity and habitat use (based on tag-derived and remotely sensed data) on long and short duration bouts. This additional informa- tion allowed us to test another prediction: habitat use (i.e. time spent and activity) varies with trip type based on the habitats visited.

\section{MATERIALS AND METHODS}

The distribution, movements at sea, diving behavior, and activity patterns of 28 sooty shearwaters were studied during the chick-rearing phase of breeding at 3 colonies in New Zealand. Two birds were studied from February to March 2003 on North East Island, the Snares Islands $\left(48^{\circ} 02^{\prime} \mathrm{S}, 166^{\circ} 36^{\prime} \mathrm{E}\right), 20$ birds were studied from January to February 2005 on Codfish Island $\left(46^{\circ} 46^{\prime} \mathrm{S}, 167^{\circ} 39^{\prime} \mathrm{E}\right)$, and 6 birds were studied from March to April 2005 on Mana Island ( $41^{\circ} 06^{\prime} \mathrm{S}, 174^{\circ} 50^{\prime} \mathrm{E}_{\text {; }}$ see Fig. 2a inset for map of colonies). All shearwaters were known breeders with 30- to 75-d-old chicks.

Sooty shearwaters return to their nesting burrows during nighttime hours only, but peak colony attendance occurs within the first hour after sunset (Weimerskirch 1998). Burrows were checked hourly between 21:00 and 02:00 $\mathrm{h}$ and again at 05:00 $\mathrm{h}$ local time. When adults were found to be tending a chick, both adult and chick were removed from the burrow and weighed with a spring balance $( \pm 10 \mathrm{~g})$. If it was determined that a chick had been fed (based on prior weighing done hours earlier), the chick was returned to the burrow and the adult was equipped with a data logger and placed back into its burrow. Upon return to the nest from a foraging excursion, both adult and chick were reweighed, the logger removed, and both birds were placed back into the burrow.

Archival tag deployments. Each shearwater was equipped with a $6 \mathrm{~g}$ Lotek LTD 2400 archival data logger (hereafter called an archival tag or tag; Lotek Wireless) following methods described by Shaffer et al. (2006). In brief, tags were mounted to a plastic leg band using UV-resistant cable ties, Tesa tape ${ }^{\circledR}$, or a rubber strap. In total, the tag and attachments weighed $<1.5 \%$ of total bird body mass.

The tags recorded ambient light intensity every $60 \mathrm{~s}$ to determine a single fix of latitude and longitude per day (i.e. Global Location Sensing [GLS] or geolocation; Wilson et al. 1992). Given the known errors in this methodology (Wilson et al. 1992, Phillips et al. 2004), especially for latitude estimates, we incorporated measurements of sea surface temperatures (SST) recorded by the tag and compared these to remotely sensed SST to refine location estimates following methods and validation described elsewhere (Teo et al. 2004, Shaffer et al. 2005). Overall great circle error estimates of our tags averaged $202 \pm 171 \mathrm{~km}$ (Shaffer et al. 2005).

Archival tag deployments were based on 2 schedules. The first involved deployments where 11 adults 
were equipped for a single trip to sea. During these deployments, tags were programmed to sample light intensity, temperature $\left( \pm 0.1^{\circ} \mathrm{C}\right.$, resolution $\left.0.05^{\circ} \mathrm{C}\right)$, and pressure $( \pm 0.1 \mathrm{~m}$, max depth $200 \mathrm{~m}$ ) every 24 (9 of 11 tags) or $32 \mathrm{~s}$ (the 2 rates are hereafter referred to as 'fast' sampling rate tags). These sampling rates were frequent enough to provide behavior over a 2 to $3 \mathrm{wk}$ deployment before tag memory filled to capacity. Trip durations were determined by monitoring colony visitations on a nightly basis. The second deployment schedule was designed to record behavior throughout the remainder of breeding and the 6 mo migration that followed (Shaffer et al. 2006). Therefore, tags were programmed to sample light, temperature, and pressure every $432 \mathrm{~s}$ (hereafter referred to as 'slow' sampling rate tags), which provided a coarser temporal resolution of behavior, but lasted over $300 \mathrm{~d}$ before tag memory filled. Regardless of sampling interval, all tags recorded the same number of bird locations (i.e. $1 \mathrm{~d}^{-1}$ ). During the latter phase of breeding (ca. March through May), colony visitations were not monitored directly; rather, trip durations were determined by evaluating track data and temperature/light records (i.e. dark burrows were generally several degrees warmer than ocean temperatures). Given the error in GLS, we used a buffer of $300 \mathrm{~km}$ around each colony. If a bird location was within this buffer and the temperatures were above $25^{\circ} \mathrm{C}$, we assumed that the bird had visited its burrow.

Analysis of geolocations, diving behavior, and activity. Location estimates were filtered for unrealistic travel rates using a speed filter (McConnell et al. 1992) with a threshold speed of $50 \mathrm{~km} \mathrm{~h}^{-1}$ (Spear \& Ainley 1997). In total, $93 \%$ of locations were kept after filtering. Track lines for each bird were created from the remaining locations using a curvilinear interpolation scheme (hermite spline; Tremblay et al. 2006) at $10 \mathrm{~min}$ intervals. The track interpolation allowed us to estimate dive locations based on synchronizing dive dates/times with the nearest location along the interpolated track. Total distance traveled and maximum distance from the colony (or range), were estimated from each interpolated track.

Given the temporal sampling rates of the loggers (24, 32 , or 432 s), we do not report exact dive durations, surface intervals, or descent and ascent rates because it is likely that birds surfaced and dove again in between sampling intervals, which would bias our estimates of these behaviors (Wilson et al. 1995a). Furthermore, we only report specific diving behaviors for tags that sampled every 24 or $32 \mathrm{~s}$. This included diving depths at sampling times, temperatures at the surface or at depth, and the frequency of diving activity, which may have been underestimated by missed dives that occurred between sampling intervals.
Diving behavior was evaluated using the Iknos Dive Analysis program (Y. Tremblay unpubl.) developed in MatLab (The MathWorks). This program performs a 0 offset correction to account for sensor drift by reevaluating the sea surface pressure level between dives. A single dive was counted and characterized if the depth was below 25 times the resolution of the pressure sensor (i.e. deeper than $2.5 \mathrm{~m}$ ) and if the duration lasted at least 2 times the sampling interval (i.e. 48 or $64 \mathrm{~s}$ ). Given our low sampling rates, these thresholds were chosen to reduce as much as possible the likelihood of concatenating consecutive dives or splitting long dives. Although not optimal, we were confident that these parameters allowed a good estimate of diving activity, even if they could not resolve fine-scale diving behavior. Based on these criteria, we estimated that $95 \%$ of all surface intervals were less than 20 min apart. Therefore, surface intervals greater than $20 \mathrm{~min}$ were used to distinguish the breaks between diving bouts.

Utilization Distribution (UD) kernels were calculated from all dive locations (2005 only) to characterize the spatio-temporal patterns of habitat use by breeding shearwaters. UD kernels were calculated using the Iknos Kernel program (Y. Tremblay unpubl.) developed in MatLab, with a grid size of $80 \mathrm{~km}$; a minimum of 2 individual birds within a grid cell were required to be counted, and each cell was normalized for bird effort by dividing each cell by the number of birds contributing to all dive locations within a grid cell (BirdLife International 2004). Spatial area was calculated for kernels after subtracting the area of each major land mass that overlapped with a UD kernel.

At-sea activity was quantified by determining when sooty shearwaters were on or off the sea surface by evaluating temperature changes measured by the loggers (Wilson et al. 1995b, Shaffer et al. 2005). Temperature data were analyzed using a purpose-built routine developed in MatLab. This routine determined when birds landed or took off from the sea surface by evaluating the rate of temperature change and the stability of the temperature once a bird was on the water (Wilson et al. 1995b). For this analysis, we only quantified activity of birds with tags that sampled at 24 or $32 \mathrm{~s}$, and we report the number of landings per day or per trip, mean durations on the water or in flight, and the proportions of each.

Habitat analyses. To examine the habitat characteristics where sooty shearwaters traveled to and conducted dives, we used tag-derived temperatures and complementary remotely sensed data. Remotely sensed data were obtained from time series of environmental data at http://coastwatch.pfel.noaa.gov/ (see website for metadata on satellite sensors and parameters). These data sets included science quality products 
for primary productivity (PP) estimated using methods described by Behrenfeld \& Falkowski (1997) with a resolution of $0.1^{\circ}$, SST that was a multiple-satellite blended product with a resolution of $0.1^{\circ}$ (see Powell et al. 2008 for details on specific SST datasets), and $3 \mathrm{~d}$ average surface wind vectors $\left(0.25^{\circ}\right.$ resolution $)$ measured from the Seawinds sensor on the QuickSCAT spacecraft (e.g. Frielich 2000). Bathymetry was extracted using data from ETOPO2 (Smith \& Sandwell 1997).

Data for each environmental parameter were extracted from the global time series within a $1^{\circ}$ longitude by $2^{\circ}$ latitude grid (the approximate error of the geolocation method) centered on the location and date of each dive. The mean $\pm \mathrm{SD}$ of the data at a given dive location were used in subsequent analyses.

Statistical analyses. All statistical analyses were performed using MatLab or SAS ${ }^{\circledR}$ (SAS Institute) with a significance level of $\mathrm{p} \leq 0.05$ for statistical tests (e.g. $t$-tests, general linear models [GLMs]). In some instances, mixed-effects analyses of variance (ANOVAs; Pinheiro \& Bates 2000) were used to test for differences between habitats (i.e. sectors) for a given environmental parameter (e.g. SST) using individual birds as a random factor in the ANOVA. Restricted Maximum Likelihood (REML) estimations were used, and because the number of observations of habitat parameters varied by individual bird, Type 3 Sums of Squares were compared to account for the unbalanced design. All data are presented as mean $\pm 1 \mathrm{SD}$.

\section{RESULTS}

Shearwaters conducted a combined total of 88 excursions across 862 bird-days at sea. Trip durations were variable between birds, but the frequency distribution
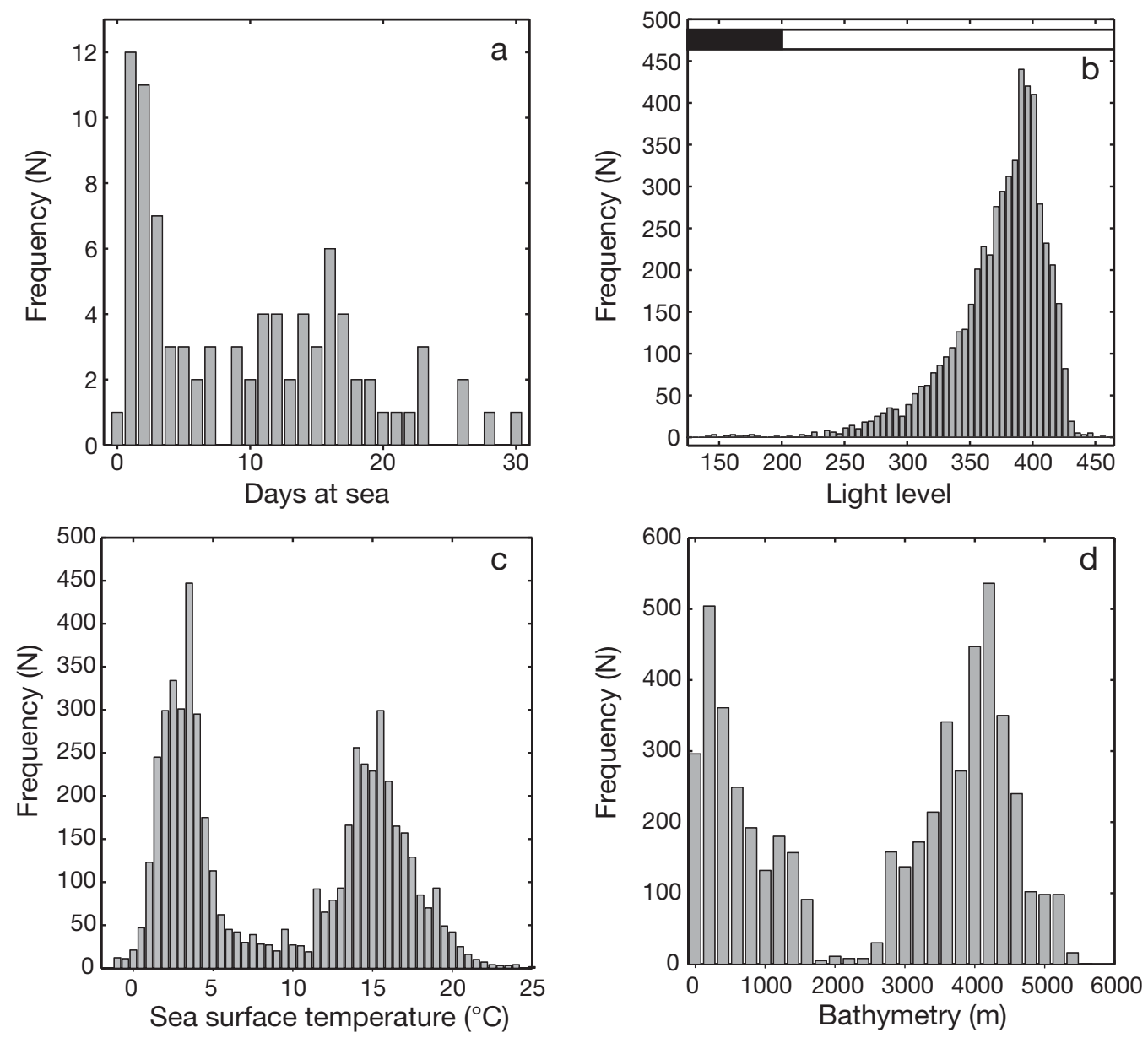

Fig. 1. Puffinus griseus. Frequency distribution of (a) foraging trip duration, (b) light level, (c) sea surface temperature, and (d) ocean bathymetry. All data were obtained by studying breeding sooty shearwaters equipped with data logging tags. In total, 88 foraging trips are shown in (a). Light levels and sea surface temperatures were recorded by the data loggers (n = 5433 observations) prior to or just after diving. Ocean bathymetry at each dive location (see Fig. 2b for dive locations) was obtained from remotely sensed data. The horizontal bar in (b) represents values for night (black) and day (white) 
of trip duration was roughly bimodal (Fig. 1a). Using $4 \mathrm{~d}$ as a cutoff between short and long trips (Weimerskirch 1998), the average duration of short trips was $1.93 \pm 0.92 \mathrm{~d}$, whereas long trips were $14.51 \pm 6.25 \mathrm{~d}$ in duration. For those individuals monitored over multiple excursions to sea ( $\mathrm{n}=17$ birds), the mean number of trips conducted by each bird was $5.1 \pm 2.2$.

\section{Distribution at sea}

Both shearwaters from the Snares Island colony traveled to oceanic waters southwest of the colony, whereas shearwaters from the Codfish Island colony traveled to coastal waters around New Zealand or to oceanic waters southwest and southeast of the colony. Shearwaters from the Mana Island colony remained in coastal waters around New Zealand or traveled to oceanic waters southeast of the colony (1 bird only).

Two main patterns of distribution were exhibited by the shearwaters. The first was the concentration of short $(n=33)$ and long $(n=17)$ duration trips within neritic waters of the New Zealand shelf (maximum range from colony was $515 \pm$ 248 km; Fig. 2a). The second pattern involved long duration trips $(\mathrm{n}=38)$ to oceanic waters southwest or southeast of each breeding colony (maximum range from colony $1970 \pm 930 \mathrm{~km}$ ). The distribution of these long trips differed in that shearwaters conducted 24 trips to oceanic waters southeast of the colony compared to only 14 trips conducted to the southwest region. Like trip duration, maximum distance from the breeding colony was also variable between and within individuals and overall varied as a function of trip duration $\left(F_{1,86}=164\right.$, $\left.\mathrm{p}<0.001, \mathrm{r}^{2}=0.653\right)$. Estimates of total distance flown by shearwaters conducting short trips along the New Zealand shelf ranged between 800 and $1500 \mathrm{~km}$ compared to estimates for trips to oceanic waters along the Polar Frontal Zone that ranged between 4500 and $12700 \mathrm{~km}$. Estimates of total distance traveled per trip also varied as a function of duration at sea $\left(F_{1,86}=435, \mathrm{p}<0.001, \mathrm{r}^{2}=0.833\right)$.
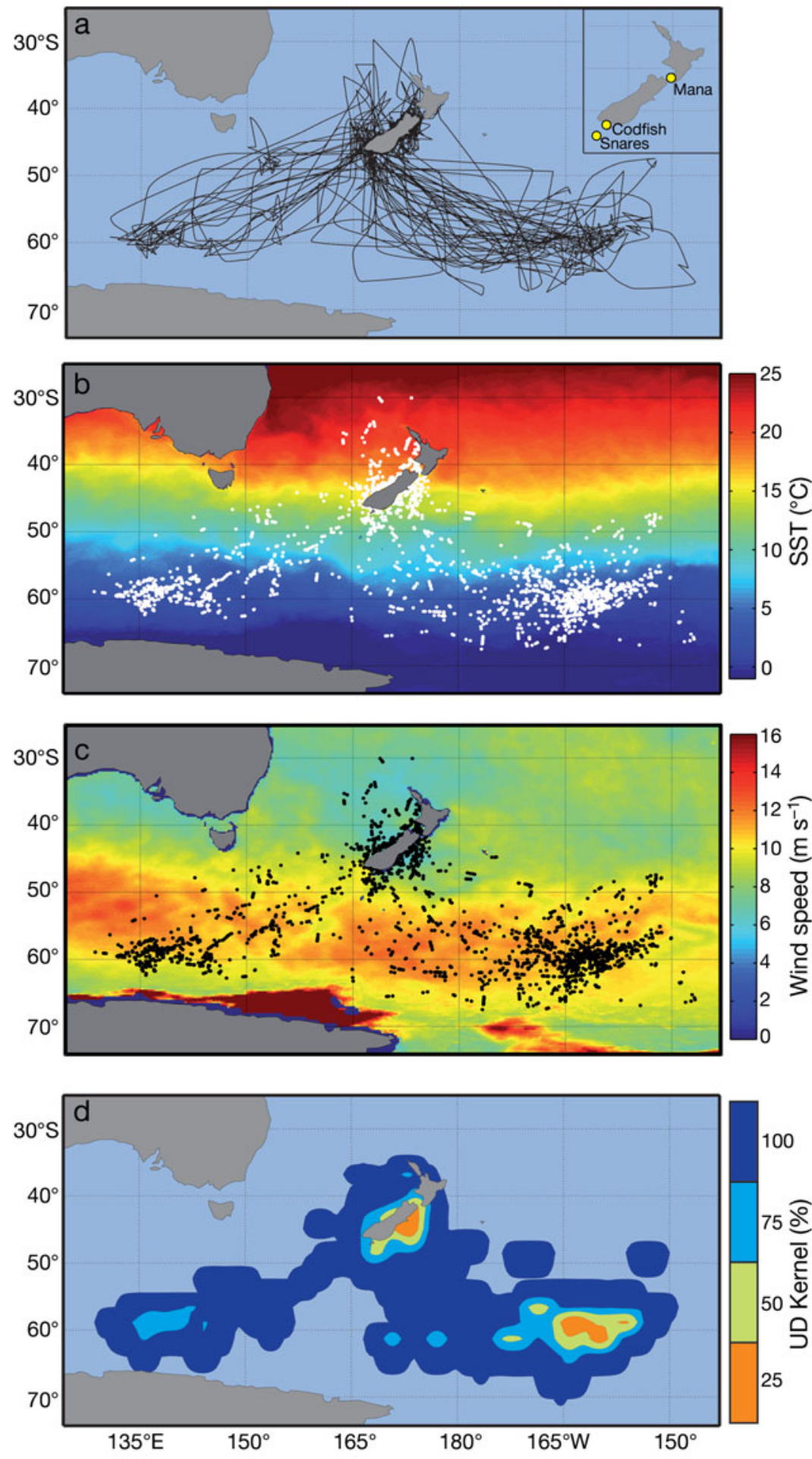

Fig. 2. Puffinus griseus. (a) Track lines of individual foraging trips made by breeding sooty shearwaters. (b) Estimates of diving location (white dots; $\mathrm{n}=$ 5433 dives) overlaid onto remotely sensed sea surface temperature (SST) in ${ }^{\circ} \mathrm{C}$. (c) Estimates of dive location (black dots) overlaid on average wind speeds in $\mathrm{m}$ $\mathrm{s}^{-1}$. (d) $25 \%, 50 \%, 75 \%$, and $100 \%$ utilization distribution (UD) kernels of the diving activity in (b). The environmental data (SST and wind speed) shown are averages across the same periods starting on 28 January 2005 and ending on 01 May 2005. Note the relative concentration of diving activity in 3 main regions 


\section{Diving behavior}

Sooty shearwaters made a combined total of 5981 dives (for 2003 and 2005), clustered in 3 discrete regions (Figs. 2b, c; only 2005 is shown). These regions exhibited the highest density of diving activity as shown by the $25,50,75$, and $100 \%$ kernel UD based on diving activity (Fig. 2d). A total of 2955 dives occurred within the $50 \%$ UD contours, comprising a total area of approximately $510600 \mathrm{~km}^{2}$.

Closer inspection of diving activity for tags with higher sampling frequencies (24 to $32 \mathrm{~s}$ intervals) revealed that sooty shearwaters were capable of diving to depths as deep as $69.9 \mathrm{~m}$ (Table 1). On average, however, diving depths were $15.9 \pm 10.8 \mathrm{~m}(\mathrm{n}=2007$ dives) with $90 \%$ of all dives occurring to depths less than $30 \mathrm{~m}$. Although it was not possible to determine dive durations accurately, given the coarse sampling intervals, we estimated that $90 \%$ of all dives were less than $100 \mathrm{~s}$ in duration.

The number of dives that individual birds made varied with trip duration, but it was also evident that birds dove in discrete bouts of activity (e.g. Fig. 3). Bouts of diving activity were interspersed between periods lasting several hours during which no diving activity was recorded (Table 1). Another pattern generally consistent for all birds was the lack of diving activity during nighttime hours (Fig. 3). Ambient light levels measured by the data loggers just before or just after a dive also confirm that $>95 \%$ of all diving activity occurred during daylight hours (Fig. 1b).

The data loggers also revealed information about the environmental conditions that shearwaters experienced while diving. For example, it was clear from water temperatures recorded by the tags that shearwaters dove in cool Antarctic waters $\left(-1.7\right.$ to $\left.5.0^{\circ} \mathrm{C}\right)$ or warmer temperate waters around the New Zealand shelf $\left(12\right.$ to $22^{\circ} \mathrm{C}_{i}$ Figs. $\left.1 \mathrm{c} \& 2 \mathrm{~b}\right)$. The frequency distribution of SSTs was distinctly bimodal with few measured SSTs in the range of 6 to $12^{\circ} \mathrm{C}$. Like SST, ocean bathymetry associated with the approximate locations of diving activity was bimodal with few dives occurring within waters that were 1500 to $3000 \mathrm{~m}$ deep (Fig. 1d).

\section{At-sea activity patterns}

Sooty shearwaters spent an average of $76.1 \%( \pm$ $9.9 \%$ ) of their total time at sea in flight, but they landed on the sea surface an average of $26.3 \pm 10.5$ times d $^{-1}$ (Table 2). Daily activity did not vary between short and long duration trips. The mean duration of each landing was $14.08 \pm 30.10$ min per event. In contrast, the average time spent in continuous flight without landing was longer and more variable (50.78 $\pm 90.24 \mathrm{~min})$.

\section{Habitat analyses}

Dive activity was not uniform among neritic or oceanic habitats (Fig. 4a). The total number of dives was greatest within waters surrounding New Zealand followed by the oceanic sector southeast of New Zealand (Fig. 4b). When normalized for numbers of individuals, however, diving effort was greatest in the southeast sector and lowest in the center sector.

Multiple trips to oceanic sectors were made by 11 $(39 \%)$ shearwaters. The remaining birds either did not visit oceanic sectors during the time that they were tracked or they visited an oceanic sector only once before the logger was recovered (i.e. short-term

Table 1. Puffinus griseus. At-sea diving behavior of breeding sooty shearwaters equipped with fast sampling tags (see 'Materials and methods' for details). The hours at sea were based on the duration between the first and last landing on the sea surface. Surface ocean temperatures were recorded by the tag just prior to diving or just after surfacing, and temperature at depth was recorded at the deepest part of the dive. Sampling interval (SI): data logger sampling frequency in seconds, IBI: inter-bout interval. Two additional birds were equipped with fast sampling tags, but no viable behavioral data were obtained due to sensor/memory failures. All data are means $\pm 1 \mathrm{SD}$

\begin{tabular}{|c|c|c|c|c|c|c|c|c|c|c|}
\hline \multirow{3}{*}{ Bird } & \multirow{3}{*}{ Hours at sea } & \multirow{3}{*}{ SI (s) } & \multicolumn{6}{|c|}{ Diving behavior } & \multicolumn{2}{|c|}{ Ocean temperature $\left({ }^{\circ} \mathrm{C}\right)$} \\
\hline & & & \multicolumn{2}{|c|}{ Dives per } & \multirow[t]{2}{*}{ \# of bouts } & \multirow[t]{2}{*}{ IBI (h) } & \multicolumn{2}{|c|}{ Depth (m) } & \multirow[t]{2}{*}{ Surface } & \multirow[t]{2}{*}{ At depth } \\
\hline & & & trip & hour & & & Mean & Max & & \\
\hline 10357 & 270.2 & 32 & 548 & 2.0 & 34 & $2.93 \pm 3.92$ & $19.4 \pm 12.1$ & 61.6 & $5.4 \pm 1.5$ & $5.3 \pm 1.1$ \\
\hline 12901 & 372.4 & 24 & 427 & 1.1 & 52 & $5.36 \pm 10.76$ & $16.6 \pm 9.8$ & 69.9 & $4.1 \pm 4.0$ & $4.0 \pm 3.9$ \\
\hline 12915 & 353.6 & 24 & 520 & 1.5 & 58 & $4.89 \pm 7.06$ & $15.0 \pm 11.1$ & 66.7 & $7.2 \pm 5.0$ & $7.1 \pm 5.0$ \\
\hline 12932 & 38.6 & 24 & 51 & 1.3 & 3 & $0.96 \pm 0.64$ & $11.4 \pm 4.0$ & 17.5 & $17.8 \pm 0.9$ & $17.4 \pm 0.8$ \\
\hline 13001 & 94.8 & 24 & 31 & 0.3 & 4 & $17.56 \pm 21.74$ & $15.8 \pm 8.2$ & 36.2 & $14.2 \pm 0.7$ & $14.0 \pm 0.7$ \\
\hline 13005 & 220.5 & 24 & 128 & 0.6 & 16 & $9.16 \pm 7.81$ & $12.6 \pm 7.5$ & 34.0 & $14.9 \pm 1.2$ & $14.6 \pm 1.0$ \\
\hline 13116 & 371.8 & 24 & 211 & 0.6 & 52 & $4.22 \pm 5.75$ & $13.4 \pm 9.2$ & 49.5 & $18.1 \pm 1.5$ & $17.8 \pm 1.3$ \\
\hline 13122 & 261.2 & 24 & 79 & 0.3 & 18 & $7.66 \pm 8.99$ & $9.7 \pm 8.8$ & 66.1 & $15.9 \pm 3.0$ & $15.7 \pm 3.0$ \\
\hline 13142 & 23.3 & 24 & 12 & 0.5 & 4 & $3.67 \pm 5.58$ & $13.2 \pm 9.0$ & 31.4 & $20.3 \pm 4.0$ & $19.9 \pm 3.7$ \\
\hline
\end{tabular}




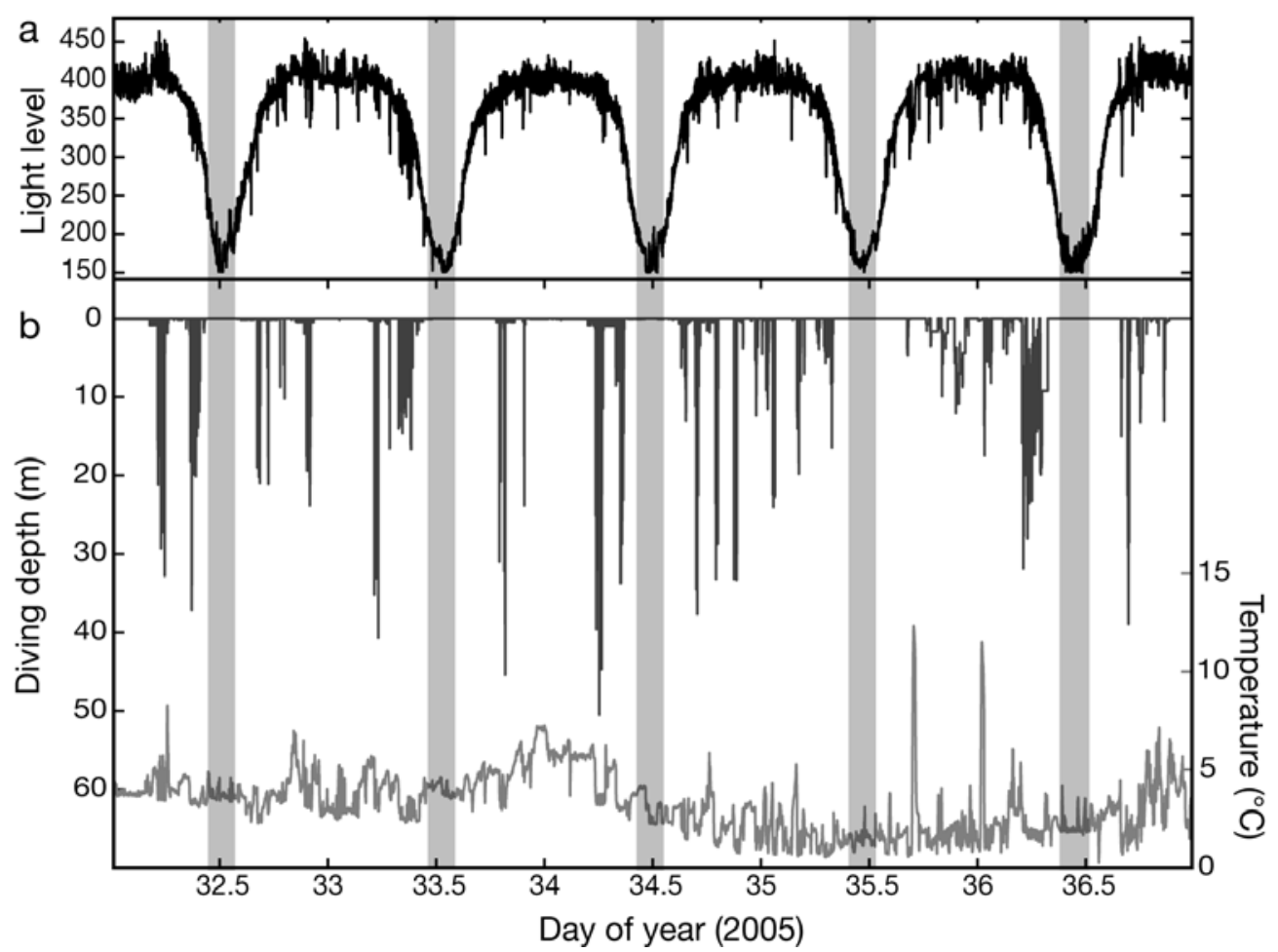

Fig. 3. Puffinus griseus. A $5 \mathrm{~d}$ portion of a $17 \mathrm{~d}$ trip to sea by a sooty shearwater (12901) equipped with a Lotek LTD 2400 archival data logger. This bird made 427 dives and landed on the sea surface 728 times during this trip (see Tables 1 \& for more details). (a) Changes in light level measured by the logger illustrating 5 day/night cycles. (b) Diving activity (dark gray line, scale on left $y$-axis) and environmental temperature (light gray line, scale on right $y$-axis) measured by the logger every 24 s throughout the trip. Note the short nights (relative light around 150), long days, and cool environmental temperatures during this portion of the record, indicative of diving activity in Antarctic waters. Also note the lack of diving activity during nighttime hours (denoted by shaded regions and see also Fig. 1b) and the prominence of diving in discrete bouts. These patterns were generally consistent across all tagged birds

deployments). Of the birds that conducted multiple trips, only $2(7 \%)$ made all trips to the same sector. Otherwise, all remaining birds visited a different sector from the previous trip at least once during the time that they were tracked. No birds visited multiple sectors in a single foraging trip.
Environmental characteristics of the core habitats were strikingly and significantly different (mixedeffects ANOVA, $p<0.001$ for all comparisons) between neritic and oceanic sectors. Bathymetry was 2000 to $3000 \mathrm{~m}$ shallower, SST was 8 to $10^{\circ} \mathrm{C}$ warmer, PP was an order of magnitude greater, and wind speeds were

Table 2. Puffinus griseus. At-sea activity and behavior of breeding sooty shearwaters equipped with fast sampling tags (see 'Materials and methods' for details). Prop: proportion of time in flight or on the water. Two additional birds were equipped with fast sampling tags, but no viable behavioral data were obtained due to sensor/memory failures. All data are means \pm SD

\begin{tabular}{|c|c|c|c|c|c|c|c|c|}
\hline \multirow[t]{2}{*}{ Bird } & \multicolumn{2}{|c|}{ Landings } & \multicolumn{3}{|c|}{ Time on water per trip } & \multicolumn{3}{|c|}{ Time in flight per trip } \\
\hline & Per trip & Per day & Prop (\%) & Mean $\pm \mathrm{SD}(\min )$ & $\operatorname{Max}(\mathrm{h})$ & Prop $(\%)$ & Mean \pm SD (min) & $\operatorname{Max}(\mathrm{h})$ \\
\hline 10357 & 365 & 32.4 & 32.6 & $14.50 \pm 43.05$ & 8.83 & 67.4 & $29.86 \pm 45.07$ & 5.87 \\
\hline 12901 & 728 & 43.0 & 23.8 & $7.96 \pm 23.38$ & 5.39 & 76.2 & $25.50 \pm 105.26$ & 23.64 \\
\hline 12915 & 507 & 33.4 & 18.4 & $7.93 \pm 7.30$ & 1.22 & 81.6 & $35.12 \pm 58.78$ & 7.63 \\
\hline 12932 & 55 & 28.7 & 21.9 & $11.16 \pm 14.35$ & 1.31 & 78.1 & $39.19 \pm 71.95$ & 6.92 \\
\hline 13001 & 93 & 22.0 & 17.8 & $11.65 \pm 31.68$ & 3.48 & 82.2 & $53.32 \pm 135.22$ & 12.00 \\
\hline 13005 & 302 & 32.8 & 30.5 & $13.38 \pm 23.10$ & 4.13 & 69.5 & $30.50 \pm 44.42$ & 5.13 \\
\hline 13116 & 479 & 30.4 & 19.0 & $9.01 \pm 27.58$ & 7.78 & 81.0 & $38.32 \pm 64.77$ & 10.77 \\
\hline 13122 & 203 & 18.6 & 36.0 & $27.88 \pm 78.93$ & 11.27 & 64.0 & $49.32 \pm 56.68$ & 6.28 \\
\hline 13142 & 35 & 32.9 & 38.3 & $16.75 \pm 27.23$ & 1.72 & 61.7 & $26.23 \pm 28.62$ & 2.18 \\
\hline
\end{tabular}



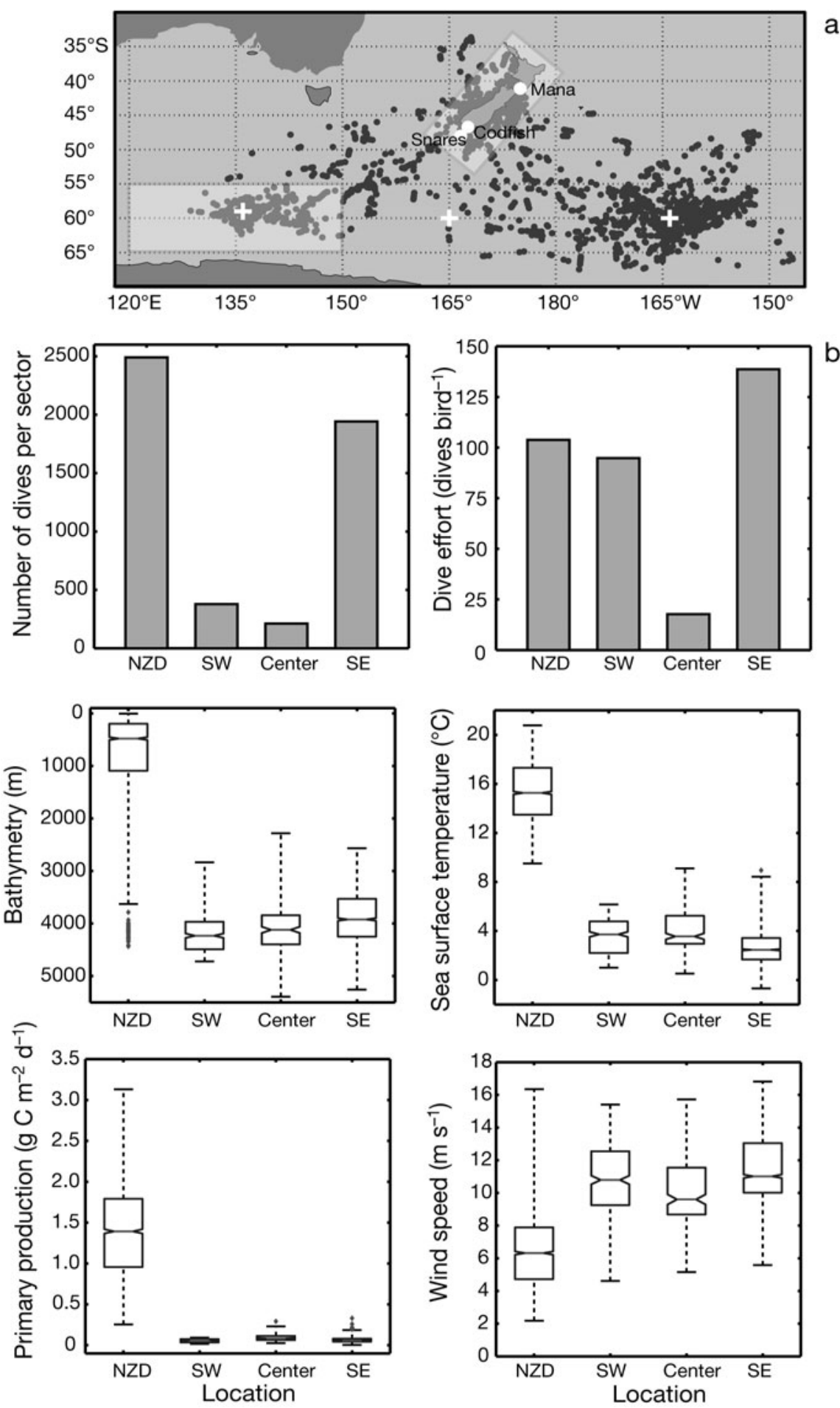

Fig. 4. Puffinus griseus. Habitat use of sooty shearwaters based on comparisons of diving activity and complementary environmental data. (a) Dive locations, partitioned into 4 quadrats (1 over neritic waters around New Zealand and 3 of equal size in oceanic waters) that generally encapsulated the core diving areas in oceanic waters (from Fig. 2d). For example, the shaded box $\left(55-65^{\circ} \mathrm{S} \times 120-150^{\circ} \mathrm{E}\right)$ encapsulates the majority of dives in the southwest (SW) sector. Similar boundaries were created for the center $\left(55-65^{\circ} \mathrm{S} \times 150-180^{\circ} \mathrm{E}\right)$, southeast $(\mathrm{SE})\left(55-65^{\circ} \mathrm{S} \times 180^{\circ} \mathrm{E}-150^{\circ} \mathrm{W}\right)$, and New Zealand sectors (NZD; shaded box around main islands). Crosses within each oceanic quadrat denote the 'center' of dive activity or the center of the quadrat, for comparison of distances to the breeding colonies (white dots). (b) Box plots (with the median, $25 \%$ and $75 \%$ quartiles, error bars representing the 1.5 SD, and points beyond as outliers) of the total number of dives, dive effort, and the values of remotely sensed environmental data for each dive location within a sector 
4 to $6 \mathrm{~m} \mathrm{~s}^{-1}$ slower in New Zealand waters compared to the oceanic sectors to the south (Fig. 4b). The oceanic sectors in Antarctic waters also differed significantly (mixed-effects ANOVA, $\mathrm{p} \leq 0.05$ ) from one another; however, the biological significance of these differences is less clear because the differences were relatively minor (Fig. 4b).

\section{DISCUSSION}

\section{Spatial patterns in at-sea distribution}

The results of our study confirm that breeding sooty shearwaters do indeed travel to Antarctic waters on long duration bouts, thus supporting our hypothesis. However, we also observed that shearwaters occasionally conducted long duration excursions around New Zealand waters. This may be influenced by colony location, as most shearwaters from the northern colony (Mana Island) remained within New Zealand waters, whereas birds from the 2 southern colonies (Snares and Codfish Islands) conducted nearly all of their long trips well south of their respective colonies. Tracking studies at the Mana Island colony commenced nearly 1 mo later (but within the same year) than those at Codfish Island, so it is possible that seasonal effects also influenced spatial patterns in habitat use. Further studies would be required to confirm this conclusion.

Given our results that sooty shearwaters will travel well over $2000 \mathrm{~km}$ from a breeding colony to forage, how prevalent is this pattern among other seabird species that have been tracked? Short-tailed shearwaters Puffinus tenuirostris and white-chinned petrels Procellaria aequinoctialis conduct extensive foraging excursions from their breeding colonies to Antarctic waters during the chick-provisioning period (Weimerskirch \& Cherel 1998, Berrow et al. 2000, Catard et al. 2000, Klomp \& Schultz 2000). For non-procellariiform seabirds, travel to these distant foraging areas over $2000 \mathrm{~km}$ away would seem prohibitive during the demanding chick-provisioning period. However, shearwaters and petrels have long slender wings like albatrosses for relatively fast efficient travel (Pennycuick 1987). Based on previous tracking studies (Klomp \& Schultz 2000, Shaffer et al. 2006), both short-tailed and sooty shearwaters are capable of traveling over $1000 \mathrm{~km} \mathrm{~d}^{-1}$. Therefore, under favorable wind conditions, these shearwaters could easily travel several thousand $\mathrm{km}$ from a breeding burrow and back in 2 to $4 \mathrm{~d}$ and still have ample time (5 to $7 \mathrm{~d}$ or more) to forage in more productive Antarctic waters.

In contrast to long duration forays to oceanic (or neritic waters), sooty shearwaters are more constrained to 'local' waters on short bouts (Fig. 2a,d). The bimodal pattern of long and short foraging bouts in sooty shearwaters (e.g. Fig. 1a), first observed by Weimerskirch (1998), is the probable reason for the cyclic attendance of nests observed in sooty shearwaters by Richdale (1963). This strategy has now been observed in shorttailed and wedge-tailed shearwaters Puffinus pacificus (Weimerskirch \& Cherel 1998, Congdon et al. 2005). Although we did not monitor colony attendance patterns and chick provisioning during the entire tracking period, the functions of these trips result in different energy intakes and flow between adults and chicks (Weimerskirch 1998, Weimerskirch \& Cherel 1998). These results are entirely consistent with our characterization of the environmental conditions of each habitat visited by the shearwaters (discussed below). Thus, the use of a dual strategy may provide adults with greater flexibility in habitat choice to facilitate energy intake or to simply 'bet hedge' in case environmental conditions or food availability are poor in 1 habitat versus another.

One of the more striking results in the foraging patterns and habitat use of sooty shearwaters revealed in our study was the concentration of diving activity in 2 distinct main oceanic regions south of the 3 colonies. The paucity of diving activity between the shelf and oceanic regions suggests that birds were primarily commuting between the colony and each core area to forage. Otherwise, we would have expected shearwaters to engage in diving activity opportunistically along the paths of their trips.

\section{Diving behavior and activity}

To our knowledge, the present study is the first to characterize the diving behavior of shearwaters using electronic tags. We are aware of diving studies on at least 6 shearwater species (5 Puffinus spp. and 1 Calonectris sp.; reviewed by Burger 2001), but these studies all used capillary tubes to measure the single deepest dive of a bird during a trip to sea. Although informative, this method provides no detail of individual diving activity, except maximum depth. In contrast, the time-depth records from our loggers showed that sooty shearwaters are prolific divers, with some birds diving more than 500 times in a single trip to sea (Table 1). The average maximum dive depth of sooty shearwaters measured with data loggers was $16 \mathrm{~m}$, but the deepest dive was $69.9 \mathrm{~m}$, nearly identical to measurements obtained with capillary tube gauges for both sooty (Weimerskirch \& Sagar 1996) and shorttailed shearwaters (Weimerskirch \& Cherel 1998). Thus, although the deepest dives are consistent with previous records obtained with capillary tubes, it is clear that sooty shearwaters dive more frequently to 
shallower depths. Compared to records of diving behavior for other seabirds, Puffinus shearwaters can dive deeper than other flying seabirds of comparable body mass (Burger 2001). Given the frequency of diving activity that we measured, our results suggest that shearwaters probably obtain more food from diving than was previously thought (Burger 2001).

We determined that sooty shearwaters dove in discrete bouts of activity, with average durations of $6 \mathrm{~h}$ between bouts of diving (Table 1). Although we were not able to accurately determine dive durations or 2-dimensional shape, we were able to resolve temporal associations in diving activity. For example, sooty shearwaters overwhelmingly dove during daylight hours (Figs. 1b \& 3). This could partially be explained by the fact that birds experienced short or even non-existent nighttime periods when foraging in the Antarctic summer. However, nearly half of all dives were conducted along the New Zealand shelf (Fig. 1d) at latitudes at or below $50^{\circ} \mathrm{S}$. At these latitudes, shearwaters would experience several hours of darkness during nighttime hours, yet $<1 \%$ of all dives were conducted in darkness (see Fig. 1b). Some dive activity was also clustered around sunrise and sunset, suggesting that sooty shearwaters possibly capitalized on prey species that migrate to the surface at night and descend during the day (e.g. crustaceans, myctophids, and squids), which is consistent with the observed diet in breeding sooty shearwaters (Kitson et al. 2000, Cruz et al. 2001).

Based on activity levels, we found that sooty shearwaters spend more than $75 \%$ of their time at sea in flight, yet land on the water an average of 27 times $\mathrm{d}^{-1}$ (Table 2). The proportion of time in flight is high compared to several albatross species, which typically spend 50 to $74 \%$ of their time at sea in flight (Shaffer et al. 2001, 2004, Weimerskirch \& Guionnet 2002, Phalan et al. 2007). However, Laysan albatrosses Phoebastria immutabilis and black-footed albatrosses $P$. nigripes spend even higher proportions of time at sea in flight (80 to $90 \%$ ) than sooty shearwaters (Fernández \& Anderson 2000). We are unaware of any other comparable data for petrels of a similar size to sooty shearwaters. Given that diving activity of sooty shearwaters is relatively high, we might expect a high frequency of landings, particularly when they are near their foraging grounds.

\section{Patterns of habitat use}

The flight paths and spatial proximity of diving activity by sooty shearwaters showed striking and somewhat unexpected variation in habitat use. It was clear that sooty shearwaters used 2 primary habitat types characterized by (1) temperate waters $\left(13\right.$ to $\left.17^{\circ} \mathrm{C}\right)$ over the New Zealand shelf and shelf edge, and (2) cold Antarctic waters $\left(2\right.$ to $\left.4^{\circ} \mathrm{C}\right)$ over deep bathymetric features. When shearwaters foraged on the shelf, diving activity was greatest along the east coast of South Island (Fig. 2d). This region is dominated by localized processes such as wind-driven coastal upwelling, relatively high PP, mixed layer depth, and physical forcing influenced by the shallow bathymetry and numerous seamounts on the New Zealand shelf (Bradford et al. 1991, Vincent et al. 1991, Murphy et al. 2001). Conversely, the distant oceanic regions where shearwaters traveled on long trips were more likely influenced by large-scale oceanic processes driven primarily by strong winds, frontal systems, and prevalence of the Circumpolar Antarctic Current (Huntley \& Niiler 1995, Constable et al. 2003). As a result, the physical processes governing each habitat type and the scales over which they occur will influence prey availability, predictability, and composition in different ways (Hunt \& Schneider 1987, Hunt et al. 1999). Supporting evidence comes from studies on the diet of breeding sooty shearwaters, which suggest variations in habitat use based on the biogeographical distribution of the prey found in the diet (Kitson et al. 2000, Cruz et al. 2001).

A comparison of habitat use by shearwaters within oceanic sectors revealed a bias towards greater activity within the southeast sector. Nearly twice the number of trips, 5 to 6 times the total number of dives, and overall dive effort was concentrated within a region along the Polar Front between 55 and $65^{\circ} \mathrm{S}$ (Fig. $4 \mathrm{a}$, b). The geographic center of this core area was approximately $2350 \mathrm{~km}$ southeast of Codfish Island compared to the other core area that was ca. $2480 \mathrm{~km}$ to the southwest of Codfish Island. Although statistically different, the oceanographic features of each sector were not dramatically different, so it is not clear why diving activity differed between sectors. However, several possible explanations merit further exploration. For example, the trajectories of prevailing wind patterns in relation to movement patterns of birds at certain points along a trip (e.g. departure from the colony or core habitat) influence large-scale movements (cf. Weimerskirch et al. 2000, Felicísimo et al. 2008, Suryan et al. 2008). It is also possible that prey resources could have been greater in the southeast region compared to the southwest, which would explain the greater visitations and activity within the southeast region. Sampling bias could also be a factor in that our sample sizes were not equivalent between the colonies monitored and were small overall compared to the population as a whole. Future studies that combine tracking with colonybased monitoring of food loads brought to the nest and/or body mass changes would undoubtedly resolve this question of habitat use. 
Acknowledgements. We thank C. Bragg, R. Mules, and B. Newton and the Tìti team for assistance in the field and K. M. Middleton for assistance with statistical analyses. We also thank the Southland Department of Conservation, New Zealand, for logistical support, as well as the crews of the Foveaux Express, Akademik Shokalskiy, Tiama, and Southland Helicopters for assistance with travel to the islands. This research was part of the Tagging of Pacific Pelagics (TOPP) program, funded in part by the Moore Foundation, Packard Endowment Grant to UCSC, the National Ocean Partnership Program (N00014-02-1-1012), and the Office of Naval Research (N00014-00-1-0880 \& N00014-03-1-0651). All protocols employed in this study were approved by the Institutional Animal Care and Use Committees at UCSC and the Southland and Wellington Conservancies of the Department of Conservation, New Zealand. Kia Mau Te Tìtī Mo Ake Tōnu Atu.

\section{LITERATURE CITED}

Ashmole NP (1971) Seabird ecology and the marine environment. In: Farner DS, King JR (eds) Avian biology, Vol 1. Academic Press, New York, p 223-286

Behrenfeld MJ, Falkowski PG (1997) Photosynthetic rates derived from satellite-based chlorophyll concentration. Limnol Oceanogr 42:1-20

Berrow SD, Wood AG, Prince PA (2000) Foraging location and range of White-chinned Petrels Procellaria aequinoctialis breeding in the South Atlantic. J Avian Biol 31:303-311

BirdLife International (2004) Tracking ocean wanderers: the global distribution of albatrosses and petrels. BirdLife International, Cambridge

Bradford JM, Cranfield HJ, Michael KP (1991) Phytoplankton biomass in relation to the surface hydrography of southern New Zealand and possible effects on the food chain. N Z J Mar Freshw Res 25:133-144

Brooke M (2004) Albatrosses and petrels across the world. Oxford University Press, Oxford

Burger AE (2001) Diving depths of shearwaters. Auk 118: $755-759$

Catard A, Weimerskirch H, Cherel Y (2000) Exploitation of distant Antarctic waters and close shelf-break waters by white-chinned petrels rearing chicks. Mar Ecol Prog Ser 194:249-261

> Chaurand T, Weimerskirch H (1994) The regular alternation of short and long foraging trips in the blue petrel Halobaena caerulea - a previously undescribed strategy of food provisioning in a pelagic seabird. J Anim Ecol 63: 275-282

Congdon BC, Krockenberger AK, Smithers BV (2005) Dualforaging and co-ordinated provisioning in a tropical Procellariiform, the wedge-tailed shearwater. Mar Ecol Prog Ser 301:293-301

Constable AJ, Nicol A, Strutton PG (2003) Southern Ocean productivity in relation to spatial and temporal variation in the physical environment. J Geophys Res 108(C4), 8079, doi:10.1029/2001JC001270

Cruz JB, Lalas C, Jillett JB, Kitson JC and others (2001) Prey spectrum of breeding sooty shearwaters (Puffinus griseus) in New Zealand. N Z J Mar Freshw Res 35:817-829

> Felicísimo AM, Muñoz J, González-Solis J (2008) Ocean surface winds drive dynamics of transoceanic aerial movements. PLoS One 3:e2928

Fernández P, Anderson DJ (2000) Nocturnal and diurnal foraging activity of Hawaiian albatrosses detected with a new immersion monitor. Condor 102:577-584
Frielich M (2000) SeaWinds: algorithm theoretical basis document. NASA ATBD-SWS-01

Hunt GL, Schneider DC (1987) Scale dependent processes in the physical and biological environment of marine birds. In: Croxall JP (ed) Seabirds: feeding biology and role in marine ecosystems. Cambridge University Press, Cambridge, $\mathrm{p} 7-41$

Hunt GL, Melhum F, Russell RW, Irons DB, Decker MB, Becker PH (1999) Physical processes, prey abundance, and the foraging ecology of seabirds. In: Adams NJ, Slotow RH (eds) Proc 22nd Int Ornith Congr, Durban, 16-23 Aug. BirdLife South Africa, Johannesburg, p 2040-2056

Huntley ME, Niiler PP (1995) Physical control of population dynamics in the Southern Ocean. J Mar Sci 52:457-468

Kitson JC, Cruz JB, Lalas C, Jillett JB, Newman J, Lyver POB (2000) Interannual variations in the diet of breeding sooty shearwaters (Puffinus griseus). N Z J Zool 27:347-355

> Klomp NI, Schultz MA (2000) Short-tailed shearwaters breeding in Australia forage in Antarctic waters. Mar Ecol Prog Ser 194:307-310

> McConnell BJ, Chambers C, Fedak MA (1992) Foraging ecology of southern elephant seals in relation to the bathymetry and productivity of the Southern Ocean. Antarct Sci 4:393-398

Murphy RJ, Pinkerton MH, Richardson KM, Bradford-Grieve JM, Boyd PW (2001) Phytoplankton distribution around New Zealand derived from SeaWiFS remotely sensed ocean colour data. N Z J Mar Freshw Res 35:343-362

Pennycuick CJ (1987) Flight of seabirds. In: Croxall JP (ed) Seabirds: feeding ecology and role in marine ecosystems. Cambridge University Press, Cambridge, p 43-62

> Pennycuick CJ, Croxall JP, Prince PA (1984) Scaling of foraging radius and growth rate in petrels and albatrosses (Procellariiformes). Ornis Scand 15:145-154

Phalan B, Phillips RA, Silk JRD, Afanasyev V and others (2007) Foraging behaviour of four albatross species by night and day. Mar Ecol Prog Ser 340:271-286

Phillips RA, Silk JRD, Croxall JP, Afanasyev V, Briggs DR (2004) Accuracy of geolocation estimates for flying seabirds. Mar Ecol Prog Ser 266:265-272

Pinheiro JC, Bates DM (2000) Mixed effects models in S and S-Plus. Springer, Berlin

Powell BS, Arrango AM, Moore A, Di Lorenzo E, Milliff RF, Foley DG (2008) 4DVAR data assimilation in the IntraAmericas Sea with the Regional Ocean Modeling System (ROMS). Ocean Model 23:130-145

Richdale LE (1963) Biology of the Sooty Shearwater Puffinus griseus. Proc Zool Soc Lond 141:1-117

Ricklefs RE (1990) Seabird life histories and the marine environment: some speculations. Colon Waterbirds 13:1-6

Schneider DC (1993) Scale-dependent spatial dynamics: marine birds in the Bering Sea. Biol Rev Camb Philos Soc 68:579-598

Schneider DC (1994) Quantitative ecology: spatial and temporal scaling, Academic Press, San Diego, CA

Shaffer SA, Costa DP, Weimerskirch H (2001) Behavioural factors affecting foraging effort of breeding wandering albatrosses. J Anim Ecol 70:864-874

Shaffer SA, Costa DP, Weimerskirch H (2004) Field metabolic rates of black-browed albatrosses Thalassarche melanophrys during the incubation state. J Avian Biol 35:551-558

Shaffer SA, Tremblay Y, Awkerman JA, Henry RW and others (2005) Comparison of light- and SST-based geolocation with satellite telemetry in free-ranging albatrosses. Mar Biol 147:833-843

Shaffer SA, Tremblay Y, Weimerskirch H, Scott D and others (2006) Migratory shearwaters integrate oceanic resources 
across the Pacific Ocean in an endless summer. Proc Natl Acad Sci USA 103:12799-12802

Smith WHF, Sandwell DT (1997) Global sea floor topography from satellite altimetry and ship depth soundings. Science 277:1956-1962

Spear LB, Ainley DG (1997) Flight speed of seabirds in relation to wind speed and direction. Ibis 139:234-251

Suryan RM, Anderson DJ, Shaffer SA, Roby DD and others (2008) Wind, waves, and wing loading: morphological specialization may limit range specialization in endangered albatrosses. PLoS One 3:e4016

Teo SLH, Boustany A, Blackwell S, Walli A, Weng KC, Block BA (2004) Validation of geolocation estimates based on light level and sea surface temperature from electronic tags. Mar Ecol Prog Ser 283:81-98

Tremblay Y, Shaffer SA, Fowler SL, Kuhn CE and others (2006) Interpolation of animal tracking data in a fluid environment. J Exp Biol 209:128-140

Vincent WF, Howard-Williams C, Tildesley P, Butler E (1991) Distribution and biological properties of oceanic water masses around the South Island, New Zealand. N Z J Mar Freshw Res 25:21-42

Warham J (1996) The behaviour, population biology and physiology of the petrels. Academic Press, San Diego, CA

Weimerskirch H (1998) How can a pelagic seabird provision its chick when relying on a distant food resource? Cyclic attendance at the colony, foraging decision and body con-

Editorial responsibility: Jacob Gonzáles-Solís, Barcelona, Spain dition in sooty shearwaters. J Anim Ecol 67:99-109

> Weimerskirch H, Cherel Y (1998) Feeding ecology of shorttailed shearwaters: breeding in Tasmania and foraging in the Antarctic? Mar Ecol Prog Ser 167:261-274

> Weimerskirch H, Guionnet T (2002) Comparative activity pattern during foraging of four albatross species. Ibis 144:40-50

Weimerskirch H, Sagar PM (1996) Diving depths of Sooty Shearwaters Puffinus griseus. Ibis 138:786-788

Weimerskirch H, Cherel Y, Cuenot-Chaillet F, Ridoux V (1997) Alternative foraging strategies and resource allocation by male and female wandering albatrosses. Ecology 78:2051-2063

- Weimerskirch H, Guionnet T, Martin J, Shaffer SA, Costa DP (2000) Fast and fuel-efficient? Optimal use of wind by flying albatrosses. Proc R Soc Lond B Biol Sci 267: 1869-1874

Wilson RP, Ducamp JJ, Rees WG, Culik BM, Nickamp K (1992) Estimation of location: global coverage using light intensity. In: Priede IG, Swift SM (eds) Wildlife telemetry: remote monitoring and tracking of animals. Ellis Horwood, New York, p 131-134

Wilson RP, Putz K, Charrassin JB, Lage J (1995a) Artifacts arising from sampling interval in dive depth studies of marine endotherms. Polar Biol 15:575-581

Wilson RP, Weimerskirch H, Lys P (1995b) A device for measuring seabird activity at sea. J Avian Biol 26:172-175

Submitted: July 31, 2008; Accepted: January 15, 2009

Proofs received from author(s): March 26, 2009 